\title{
A Comparative Analysis of the Regional Consciousness of Students Living in Russian-EU and Russian-China Border Regions (actual problems of cognition of socio-cultural space)
}

\author{
RENALD SIMONYAN \\ MGIMO University under the Ministry of Foreign Affairs of the Russian Federation, Prospekt Vernadskogo, 76, Moscow, Russia, 119574; \\ Institute of Economics of the Russian Academy of Sciences, Nakhimovsky Prospekt, 32, Moscow, Russia, 117997 \\ Email:sim@isras.ru
}

\begin{abstract}
This paper considers the growing role of regions in the current stage of globalization and demonstrates the need to move away from the economic aspects of regional studies that dominate the discipline today to the socio-psychological aspects - to perceptions, attitudes, value preferences, orientations and dispositions that characterize the mass consciousness which underlies the activities of people to further the socioeconomic development of regions. The author analyses the sociological phenomenon of 'regional consciousness' and why we should study it and, within the framework of a new area of regional science - cross-border regional studies, presents the findings of the first comparative study covering the features of regional consciousness. Russian graduates from leading universities in the eastern and western border regions of the Russian Federation were chosen as the subjects for this research, as they represent the most active and high-potential population group in the country.
\end{abstract}

Keywords: philosophy of space, cross-border regional studies, public consciousness, regional consciousness

\section{INTRODUCTION}

Regional studies that are based on economic geography have traditionally focused on economic aspects. Even today, the overwhelming majority of academic literature on regional studies is produced by economists.

At the same time, the growing interest in regional science that we have witnessed over the past few decades all over the world is not the result of economic necessity alone, as more and more people are drawn to the subject. The magnitude of global contradictions at the end of the 20th century forced researchers to turn their attention to the social aspects of regional development and, above all, its human potential. Regional characteristics affect the mass consciousness of the local population, which in turn influences regional processes, including 
economic ones, as the human factor is fundamental in all stages of the economy: production, distribution, exchange and consumption. Sociologists who study the nature of consciousness emphasize the causal relationship between consciousness and activity, since 'human consciousness is the internal movement that stimulates practical action, and it is practical action that determines the individual's real life in society. Human activity is the substance of human consciousness' (Zinchenko 2006: 218).

Regions have always played, and will continue to play, an important and sometimes decisive role in the formation and development of states. It is for this reason that we cannot gain a true understanding of a given country or people without first studying individual regions and their human potential. F. Braudel stressed that 'the philosophical understanding of the region lies in the identity of the region as a special world with its own mentality, way of thinking, traditions, world view and attitudes (Braudel 1994: 259).

Until now, the spatial segmentation of global spiritual processes remains a little-studied area of scientific knowledge.

\section{REGIONAL CONSCIOUSNESS}

This fully applies to regional consciousness, or the way a group community perceives itself that emerges as a result of a sense of the unity of the territory. The term 'regional consciousness' itself entered scientific discourse relatively recently.

Just as a region is an interconnected part of a country as a whole, regional consciousness is a part of the public consciousness of a country as a whole, and both are independent fields of knowledge.

The classic scholars of the sociology of human consciousness (Jacob Burckhardt, Erich Fromm, José Ortega y Gasset and Herbert Marcuse, among others) formulated a fundamental provision that one of the distinctive features of the analysis of mass consciousness is that, as it is just one of the forms of consciousness, we can only describe its state at a very definite and real level, and we must always bear in mind the specific features of the subject. Developing this idea in his seminal work Mass Consciousness: Definition and Research Issues, the Russian thinker B. Grushin (Grushin 1987) put forward the concept of the multiplicity of the mass consciousness that exists in various parts of society and demonstrated the need to study specific carriers of mass consciousness. This notion also fully applies to the population of a given region, as their mass consciousness reflects the specific features of the region in general. 'We do not need any other universal postulates other than the universal law of geography, which states that all regions are unique and inimitable' (Hartshorne 1999: 187).

This postulate is particularly relevant for the Russian Federation, whose regions demonstrate a unique natural, cultural, historical, social, demographic, ethnocultural, economic, political, social and psychological diversity. It would not be a stretch to say that Russia's regions differ from each other more than the individual states of the European Union do.

It has long been accepted in modern Russian discourse that Russians know little about their country (Bessonova 2008; Time 2009; Volkov, Lubsky 2018). We are not talking about economic differences here, as these have been explored in great detail in reference works that regularly present the economic. It is the most complex and most important aspect, namely, the social and psychological sphere - the system of representations, values and behavioural patterns that make up public consciousness - that remains somewhat of a mystery.

This lack of public self-consciousness was perfectly summed up by the editor-in-chief of the journal Notes of the Fatherland Tatyana Malkina when she wrote, 'Any - even the most 
superficial - attempt to study the Russian space with everything that lives, grows and thinks in it, will immediately discover the main problem of this space: that it does not know itself at all. The Russian space is poorly studied and poorly understood' (Malkina 2007: 10).

The lack of knowledge about regional consciousness is a global phenomenon. And the term 'regional consciousness' has only recently begun to gain traction in the academic literature. Works on mass consciousness have started to appear in individual regions over the past few years (Kubátová 2016; Smoliak, Smoliak 2019; Prokkola 2019). At the same time, the social status of the region being studied and its role in global processes are of theoretical and practical importance.

\section{THE FEATURES OF BORDER REGIONS}

One of the most significant global processes unfolding today is the rapid increase of inter-civilizational, intercultural and international interaction. This has the knock-on effect of amplifying the role of regions where such interaction takes place directly - cross-border regions. This is especially true for Russia, as it has the longest border than any country in the world and the largest number of neighbouring civilizations, cultures and states. No fewer than 47 of the 85 constituent entities of the Russian Federation border another country. What is more, in addition to the general differences, Russia's border regions have a number of features that are inherent to them. As a rule, the Russian border zone is located far from the centre and is made up of territories with poorly developed industry - a result of the quite natural desire to avoid building large economic complexes near the state borders. This explains why these areas are sparsely populated and have limited opportunities for economic growth.

An important feature of the border regions is that their status is not entirely clear. On the one hand, they are the back country, depressed regions. On the other, they are a politically significant centre, an important node of interaction between neighbouring states and societies that gives rise to a third, intermediate society - a border society that has its own objective and subjective features (Simonyan 2010). State borders fulfil two essential functions: they serve as a barrier between two countries and provide a means for developing friendly contacts between the peoples of those countries. In other words, they are an outpost for protecting the territory of and keeping public order in a given country and ensuring interaction (economic, cultural and environmental) with neighbouring states. These functions are carried out through the consciousness and behaviour of the people, because a border is not simply an international legal institution that ensures the inviolability and integrity of a given territory. It is also a product of public practice, that is, of the actions of those who live in border regions.

Living next to a state border affects the way people behave - 'there is a line that marks the boundary between what is "ours" - "our culture" and what we see as "safe" and what is "theirs", "alien", "hostile", "dangerous", etc'. (Lotman 2000: 276); in other words, it is a feature of mass consciousness that is known as 'border syndrome'.

Social scientists have long known about the unique mentality of people who live in border regions. As early as the beginning of the 20th century, G. Simmel rightly noted that the social boundary is 'not a spatial fact with sociological consequences, but a sociological fact that is formed spatially' (Simmel 1996: 599).

\section{RESEARCH PROBLEM}

By studying the mass consciousness and everyday behaviour of people who live in border regions, we can gain an understanding of how this space of intercultural dialogue is formed, 
how its elements work, what rules determine the behavioural strategies of the population, what role the border plays in these processes and how border regions differ according to these and other parameters.

For the purposes of this study, we carried out a comparative analysis of the regional consciousness of graduates living in the Russia-EU and Russia-China border regions.

There has been a noticeable increase in the political activity of young people in Russia over the past decade. This is what makes studying this population group particularly relevant, as the collective psychology of the new, post-Soviet generation is of acute public interest today.

As for how we selected the border regions for this study, the decision was informed by the growth of economic cooperation between Europe and Asia and the fact that Russia belongs to both continents, occupying a geostrategic position between two of the three leading centres of the global economy - the European Union (which accounts for 22.6\% of global GDP) and China (16.5\% of global GDP). The regional capitals that most fully represent East and West were selected. The main criteria for assessing which were most representative were the length of the state border, the degree of economic and sociocultural interaction of the region with the neighbouring state, and the proximity of the region's capital to the border.

\section{THE REGIONAL CONSCIOUSNESS OF STUDENTS: DIFFERENCES BETWEEN EAST AND WEST (ON THE BASIS OF THE SURVEY)}

In order to conduct a comparative analysis of the mass and group consciousness of the two border regions, we conducted interviews with undergraduate and graduate students at the following universities in December 2018: in the West - Immanuel Kant Baltic Federal University (Kaliningrad), St. Petersburg State University and Petrozavodsk State University; and in the East - Pacific National University (Khabarovsk), Amur State University (Blagoveshchensk) and Far Eastern Federal University (Vladivostok). The number and size of faculties met the criteria of a representative sample. We received a total of 1,630 completed questionnaires: 250 from Kaliningrad, 380 from St. Petersburg, 220 from Petrozavodsk, 240 from Blagoveshchensk, 280 from Khabarovsk and 260 from Vladivostok. The questionnaire itself consisted of seven sections: personal data, cultural and religious views, views about contemporary Russia and the future of the country, attitudes towards neighbouring countries and their relations with Russia, an assessment of regional problems; future plans and attitude to life, attitude towards migrants and migration, and level of awareness and sources of information.

Young specialists are the core of the labour and creative potential of the Russian border region.

Students have the most geographic mobility and are the most cosmopolitan of all population groups. They do not feel as attached to the region as the older generations, are less inclined to follow the traditions of their ancestors or be drawn to the soil-bound tradition, and they are not weighed down by the burden of responsibility for the current state of the country. This makes comparing the regional consciousness of representatives of this social group - a consciousness that has been formed in the context of globalization - which occupies a special place in society (Simonyan 2012) purer from the point of view of scientific study.

That being said, there were significant differences in the mass consciousness of functionally similar regions even among this most homogeneous of groups. And the differences started with how the respondents self-identify (Table 1). 
Table 1. Personal identification

\begin{tabular}{c|c|c|c|c|c|c}
\hline & \multicolumn{3}{|c|}{ West } & \multicolumn{3}{c}{ East } \\
\hline $\begin{array}{c}\text { Self- } \\
\text { identification }\end{array}$ & Kaliningrad & Petersburg & Petrozavodsk & $\begin{array}{c}\text { Blagovesh- } \\
\text { chensk }\end{array}$ & Khabarovsk & Vladivostok \\
\hline By nationality & 33.8 & 31.5 & 43.4 & 63.3 & 56.0 & 63.5 \\
\hline By ethnicity & 44.2 & 32.9 & 37.8 & 27.8 & 31.6 & 27.1 \\
\hline $\begin{array}{c}\text { By region of } \\
\text { origin }\end{array}$ & 11.3 & 13.0 & 10.1 & 4.3 & 4.1 & 3.2 \\
\hline $\begin{array}{c}\text { By city of } \\
\text { origin }\end{array}$ & 11.7 & 22.6 & 8.7 & 4.6 & 8.3 & 6.2 \\
\hline
\end{tabular}

People from the Russian Far East tend to identify themselves by nationality. The people who live in these border regions are aware that they are small in number and, thus, vulnerable. Therefore, belonging to the state is not only a fundamental value, but also a security instinct. The border factor has penetrated deeper into the consciousness of people from the Russian Far East. On average, people from the East identified themselves first and foremost by nationality in $60.4 \%$ of cases, compared to $37.3 \%$ for those from the West.

Ethnicity is important to the populations of a number of Russian regions when it comes to self-identification, often more so than nationality. This is a reflection of the process of regionalization. Ethnic identity tended to be more important to people living on Russia's Western border $-38.6 \%$ compared to $28.9 \%$. To some extent, this can be attributed to the fact that more ethnic Russians live in the East of the country ( $96.7 \%$ compared to $85.4 \%$ in the West).

The respondents also differed in how they view their financial status (Table 2). Despite the fact that people in the Western regions have more money (the 2018 rating of living standards in Russia's regions demonstrates this), people in the East tend to see themselves as wealthier.

This can largely be explained by the specifics of neighbour relations. Self-worth is formed by comparison with others. People who live on Russia's western borders will come out on the losing end if they compare their standard of living with that of Lithuanians, for instance, even more so if they choose to compare themselves with Poles or Estonians. However, compared to China, the standard of living in Russia is better. According to the International Monetary Fund (IMF), GDP per capita by purchasing power parity in 2019 was $\$ 27,951$ in Russia, compared to $\$ 18,508$ in China.

The fact that Russia straddles two continents and occupies a central or axial ('Heartland') position on the Eurasian continent has been noted by all leading geopolitical observers, from H. Mackinder (Mackinder 1904) and K. Haushofer (Haushofer 1925) to A. Chauprade

Table 2. Financial situation

\begin{tabular}{c|c|c|c|c|c|c}
\hline \multirow{2}{*}{$\begin{array}{c}\text { Financial } \\
\text { status }\end{array}$} & \multicolumn{3}{|c|}{ West } & \multicolumn{3}{c}{ East } \\
\cline { 2 - 7 } & Kaliningrad & Petersburg & Petrozavodsk & $\begin{array}{c}\text { Blagovesh- } \\
\text { chensk }\end{array}$ & Khabarovsk & Vladivostok \\
\hline Good & 28.0 & 26.3 & 26.5 & 40.3 & 32.5 & 45.2 \\
\hline Average & 56.7 & 53.2 & 60.2 & 51.2 & 56.5 & 51.1 \\
\hline Below average & 15.3 & 20.5 & 13.3 & 8.5 & 11.0 & 3.7 \\
\hline
\end{tabular}


(Chauprade 2007) and Z. Brzezinski (Brzezinski 2010). The problem of the 'European' and 'Asian' influences on the Russian mentality has been a part of Russian discourse since the time of Peter the Great.

When given the choice between 'individual' and 'state' values, students in eastern and western Russia demonstrate the priority of European values in regional consciousness (Table 3). Statehood is not common in representatives of this population group (11.3-17.2\% of respondents), despite its popularity in Russia as a whole.

Most students in regions where the state is held in a particularly high regard privilege the core value of European civilization, namely, the individual. And there is a little difference in the opinions of people living in the West and East of the country (82.1\% compared to $78.7 \%$ on average). This notwithstanding, independent thinking is still more characteristic of people from the West, while those in the East are more likely to conform.

These differences are highlighted in the assessment of the current situation in Russia (following the events in Donbas). The following table (Table 4) shows how respondents answered the question, 'Do you think that the situation in Russia is developing positively?'

The results are not flattering in the least, although it is clear that people in the West are far more critical of the current situation than people in the East (29.2\% compared to $18.3 \%)$. These responses are symptomatic of a number of problems facing young people today: unemployment, the lack of social elevators and the poor quality of life. A number of Russian universities have effectively been training students for foreign labour markets over the past several years. The state is losing human capital, as university graduates who cannot find a job in their field in Russia are now helping to develop the scientific and technical potential of other countries. The dissatisfaction with the social processes that are taking place in the country are reflected in the growing number of young Russian professionals considering emigrating to another state (Table 5).

Table 3. State and liberal values

\begin{tabular}{c|ccccccc}
\hline & \multicolumn{3}{|c|}{ West } & \multicolumn{3}{c}{ East } \\
\cline { 2 - 7 } & Kaliningrad & Petersburg & Petrozavodsk & Blagoveshnsk & Khabarovsk & Vladivostok \\
\hline State & 16.2 & 11.3 & 14.3 & 15.5 & 11.7 & 17.2 \\
\hline Individual & 78.5 & 86.7 & 81.5 & 75.3 & 81.5 & 77.8 \\
\hline Not sure & 5.3 & 2.0 & 4.2 & 9.2 & 6.8 & 5.0 \\
\hline
\end{tabular}

Table 4. Assessment of the company's development trajectory

\begin{tabular}{ccccc|c|c|c}
\hline & \multicolumn{3}{|c|}{ West } & \multicolumn{3}{c}{ East } \\
\cline { 2 - 8 } & Kaliningrad & Petersburg & Petrozavodsk & Blagoveshchensk & Khabarovsk & Vladivostok \\
\hline Agree & 11.6 & 3.5 & 4.0 & 11.7 & 4.5 & 7.5 \\
\hline $\begin{array}{c}\text { Probably } \\
\text { agree }\end{array}$ & 24.8 & 15.2 & 31.3 & 32.0 & 31.3 & 35.3 \\
\hline $\begin{array}{c}\text { Probably } \\
\text { disagree }\end{array}$ & 34.6 & 36.3 & 32.7 & 34.3 & 33.5 & 28.5 \\
\hline Disagree & 22.5 & 43.5 & 21.5 & 18.5 & 19.7 & 16.7 \\
\hline Not sure & 6.5 & 1.5 & 10.4 & 13.5 & 11.0 & 12.0 \\
\hline
\end{tabular}


Table 5. Setting up for emigration

\begin{tabular}{c|c|c|c|c|c|c}
\hline & \multicolumn{3}{|c|}{ West } & \multicolumn{3}{c}{ East } \\
\cline { 2 - 7 } & Kaliningrad & Petersburg & Petrozavodsk & $\begin{array}{c}\text { Blagovesh- } \\
\text { chensk }\end{array}$ & Khabarovsk & Vladivostok \\
\hline Positively & 59.3 & 53.6 & 55.0 & 62.3 & 51.7 & 50.8 \\
\hline Negatively & 22.0 & 21.3 & 24.7 & 18.5 & 21.6 & 25.8 \\
\hline Not sure & 18.7 & 25.1 & 20.3 & 19.2 & 26.7 & 23.4 \\
\hline
\end{tabular}

Attitudes towards emigration were practically identical in the East and West of Russia, which speaks of the homogeneity of the population group we are studying. The number of people who responded positively, negatively or were not sure was almost exactly the same across the board. Those who live in cities that enjoy active contacts with neighbouring countries tended to be more positive about emigration as a whole: Kaliningrad and Blagoveshchensk are very close to the borders, which explains why their residents, who have more experience with the everyday life of foreign countries, are more inclined to emigrate abroad. Residents of St. Petersburg and Khabarovsk turned out to be the most contemplative in this respect, as over one quarter of respondents in each city were unable to answer the question.

Still, even this relatively homogenous community demonstrated regional differences with regard to most characteristics that make up the mass consciousness. These differences were most pronounced when it came to attitudes towards national security, as the assessments of the risk factors facing the country differed in East and West (Table 6).

One possible reason for these differences in the fact that Russia's immediate neighbours to the west are predominantly small countries, whereas its immediate neighbour to the east is a powerful state that harbours lofty ambitions and whose population (and GDP for that matter) is ten times the size of Russia. What is more, the residents of the Russian Far East are thousands of miles away from the centre of the country, where the roots of all its social contradictions are concentrated. As a result, they do not perceive internal threats with the same gravitas as those in the West of the country.

Given the fact that a significant number of respondents were open to emigration, it was important to find out what they thought about other states. We asked those who took part in the survey to tell us which country in their opinion had developed the most optimal social structure and tabulated the results (Table 7).

Table 6. Sources of threats

\begin{tabular}{c|c|c|c|c|c|c}
\hline \multirow{2}{*}{$\begin{array}{c}\text { Sources of } \\
\text { threat to } \\
\text { the state }\end{array}$} & \multicolumn{3}{|c|}{ West } & \multicolumn{3}{c}{ East } \\
\cline { 2 - 7 } & Kaliningrad & Petersburg & Petrozavodsk & $\begin{array}{c}\text { Blagovesh- } \\
\text { chensk }\end{array}$ & Khabarovsk & Vladivostok \\
\hline External & 30.7 & 27.2 & 28.5 & 52.3 & 51.0 & 60.2 \\
\hline Internal & 55.0 & 62.5 & 54.3 & 27.5 & 34.6 & 24.8 \\
\hline Not sure & 14.3 & 10.3 & 17.2 & 20.2 & 14.4 & 15.0 \\
\hline
\end{tabular}


Table 7. The best state structure

\begin{tabular}{c|c|c|c|c|c|c}
\hline \multirow{2}{*}{$\begin{array}{c}\text { Fairest } \\
\text { societal } \\
\text { structure }\end{array}$} & \multicolumn{3}{|c|}{ West } & \multicolumn{3}{c}{ East } \\
\cline { 2 - 7 } & Kaliningrad & Petersburg & Petrozavodsk & $\begin{array}{c}\text { Blagovesh- } \\
\text { chensk }\end{array}$ & Khabarovsk & Vladivostok \\
\hline Russia & 16.4 & 10.7 & 15.3 & 19.7 & 16.7 & 18.3 \\
\hline EU & 34.3 & 43.6 & 39.1 & 21.6 & 24.2 & 22.7 \\
\hline China & 8.0 & 7.8 & 12.6 & 13.2 & 10.7 & 9.4 \\
\hline USA & 15.8 & 16.3 & 13.5 & 16.5 & 16.2 & 16.5 \\
\hline Japan & 19.5 & 16.6 & 15.5 & 21.5 & 24.9 & 26.6 \\
\hline $\begin{array}{c}\text { Islamic } \\
\text { Countries }\end{array}$ & 3.3 & 3.5 & 2.2 & 3.5 & 3.8 & 3.0 \\
\hline Not sure & 2.7 & 1.6 & 2.0 & 4.0 & 3.5 & 3.5 \\
\hline
\end{tabular}

Respondents from the West have Russia in the fourth place (behind the European Union, Japan and the United States), while those from the East have Russia in the third place (behind Japan and the European Union). It is hardly a surprise that Japan took the first place in Khabarovsk and Vladivostok, and joint the first place with the European Union in Blagoveshchensk (i.e. in the East of Russia). Japan is one of the leading countries in the world in terms of scientific and technological progress. The country has a high standard of living and the highest life expectancy in the world. Its democratic structure and unique culture are attractive to foreigners.

Effective cooperation depends on how well the partners know each other. The following table (Table 8) shows how respondents in the East and West of Russia view how well Russians and their respective neighbours know each other.

According to the respondents, Russian people know more about the European Union than Europeans know about Russia. And it is those who live on the Russia-EU border who are the most convinced of this ('the West doesn't understand us'), at 46.8 and $11.2 \%$, compared to 37.6 and $20.9 \%$ for those who live on the Russia-China border. At the same time, Russians

Table 8. Mutual awareness of neighbours

\begin{tabular}{c|c|c|c|c|c|c}
\hline \multirow{2}{*}{$\begin{array}{c}\text { Who knows } \\
\text { more } \\
\text { about their } \\
\text { neighbours? }\end{array}$} & Kaliningrad & Petersburg & Petrozavodsk & $\begin{array}{c}\text { Blagovesh- } \\
\text { chensk }\end{array}$ & Khabarovsk & Vladivostok \\
\cline { 2 - 7 } $\begin{array}{c}\text { Russians } \\
\text { about the EU }\end{array}$ & 47.4 & 51.0 & 42.2 & 33.0 & 36.7 & 43.3 \\
\hline $\begin{array}{c}\text { EU citizens } \\
\text { bbout Russia }\end{array}$ & 11.2 & 9.5 & 13.1 & 19.3 & 15.6 & 17.8 \\
\hline $\begin{array}{c}\text { Russians } \\
\text { about China }\end{array}$ & 23.3 & 21.0 & 29.2 & 26.5 & 24.3 & 32.7 \\
\hline $\begin{array}{c}\text { Chinese } \\
\text { about Russia }\end{array}$ & 39.5 & 38.5 & 28.7 & 46.7 & 42.7 & 41.2 \\
\hline
\end{tabular}


living in both border regions acknowledge that the Chinese know more about Russia than vice versa: 43.5 to $27.8 \%$ in the East and 35.8 to $24.4 \%$ in the West. This corresponds with what respondents know about their neighbours from a personal experience: $37.5 \%$ in Kaliningrad, 26.3\% in Petrozavodsk, 44.5\% in St. Petersburg, 89.5\% in Blagoveshchensk, 57.3\% in Khabarovsk and $59.0 \%$ in Vladivostok. Respondents in the East are much more likely to visit China than respondents in the West are to visit one of their neighbours, because the visa regime with China is less strict. Respondents from both sides of Russia get most of their information about their neighbours from social networks, rather than from television, but the difference is greater in the West. This is proof once again of the sceptical nature of those living in the Western border region, and the trusting nature of those in the Eastern border region.

\section{CONCLUSIONS}

The proximity of another country sublimates the sense of the 'last frontier' in the mass consciousness of people who live in border regions and strengthens the 'us against them' mentality, regardless of the civilizational (in the East) or sub-civilizational (in the West) differences. Yet, even in such a homogeneous social group as student youth, significant regional differences, primarily of a geographic nature, nevertheless manifested themselves. The most important political events today are taking place in Europe. As a result, it is those who live in the Western border region who are more clued in on global affairs: liberal and democratic values prevail; ethnic identity is valued above national identity; there is less optimism about the future; people demonstrate a greater ability to think for themselves when evaluating events taking place in the country; there is greater scepticism towards the authorities; border syndrome is less pronounced; and people are not as suspicious of their neighbours. People in the East are more conservative: they believe in statistics, are more religious and hopeful for a better future. They demonstrate greater conformity and tolerance, fear of external threats and are less critical of the authorities. We should also highlight what is perhaps the most important feature of people in the East, and that is the sheer number of people who could not, or refused to, give an answer to the questions asked. While people in the West have generally thought through and made sense of many of today's social phenomena, those in the East are still meditating on these issues.

\section{ACKNOWLEDGEMENTS}

The reported study was funded by MGIMO-University, Project No. 1921-01-01.

Received 11 June 2020 Accepted 15 October 2020

\section{References}

1. Bessonova, O. 2008. 'General Theory of Institutional Transformations: A Paradigmatic Rethinking of the Civilizational Development of Russia', Sociological Studies 1: 12-19.

2. Braudel, F. 1994. The Identity of France. Vol. 1: History and Environment. Moscow: Sabashnikov Publishing House.

3. Brzezinski, Z. 2003. The Grand Chessboard. Moscow: Mezhdunarodnye otnosheniya.

4. Chauprade, A. 2007. Géopolitique - Constantes et changements dans l'histoire. Paris.

5. Grushin, B. 1987. Mass Consciousness: Definition and Research Issues. Moscow.

6. Hartshorne, R. 1959. Perspective on the Nature of Geography. Chicago.

7. Haushofer, K. 1925. Geopolitik des Pazifischen Ozeans. Wien.

8. Kubátová, H. 2017. 'Collective Memory and Collective Identity of Hlučín Region Inhabitants in the 20th Century', Historicka Sociologie 1: 11-32. 
9. Lotman, Y. 1996. Inside Thinking Worlds. Moscow: Yazyki russkoi kulturoi.

10. Mackinder, H. 1904. 'The Geographical Pivot of History', The Geographical Journal 23(4): 421-437.

11. Malkina, T. 2007. 'Outline Map', Notes of the Fatherland 6: 9-17.

12. Simmel, G. 1996. Collected Works. Vol. 2: The Contemplation of Life. Moscow: Yurist.

13. Simonyan, R. 2010. 'The Concept of Mesoscale as Applied to the Region', Sociological Studies 5: 51-62.

14. Simonyan, R. 2012. 'The Reforms of the 1990s and the Modern Social Structure of Russian Society', Sociological Studies 1: 37-47.

15. Smoliak, P.; Smoliak, O. 2019. 'Ethnographic Boundaries of Western Podillya: History of Formation and Ethnic Identity', Astra Salvensis 7(13): 45-59.

16. Prokkola, E.-K. 2019. 'Regional Consciousness and the Hierarchy of Border Crossing Mobilities: Residents' Perspectives in Lappeenranta and Tornio', Terra 2(131): 81-95.

17. Time, G. 2009. 'From St. Petersburg to Moscow with a Stop-off in Berlin (The Road to Russia's Selfidentification in the 20th Century)', Problems of Philosophy 10: 16-31.

18. Volkov, Y.; Lubsky, A. 2018. 'Sociology as a Way for Society to Understand Itself', Sociological Studies 7: 3-12.

19. Zinchenko, V. P. 'Consciousness as a Subject and Matter of Psychology', Methodology and History of Psychology 1(1): 207-231.

RENALDAS SIMONIANAS

\title{
Rusijos-Europos ir Rusijos-Kinijos paribio studentijos regioninès savimonès palyginamoji analizè
}

\begin{abstract}
Santrauka
Straipsnyje nagrinejjamas didejjantis regionų vaidmuo dabartiniame globalių procesų etape. Siekiama nutolti nuo dominuojančio ekonominio aspekto ir pereiti prie socialinio-psichologinio (vertybinio) požiūrio, lemiančio žmonių veiklą ir regionų socialinę-ekonominę raidą. Straipsnyje nagrinèjama „regioninè savimoné, pateikiami pirmųjų Rusijoje palyginamųjų paribio regionų tyrimo rezultatai. Tyrimo objektu pasirinkta aktyviausia ir perspektyviausia gyventojų grupe - studentija.
\end{abstract}

Raktažodžiai: paribio regionai, jaunimo sociologija, regioninè savivoka 